\title{
Spatio-temporal viewer on the incidence of cases of Covid-19 in the Mexico-United States cross-border strip ${ }^{\text {तै }}$
}

\section{Visualizador espacio-temporal de la incidencia de casos de COVID-19 en la franja fronteriza México-Estados Unidos}

\author{
Iván Alejandro Martínez Zazueta*a ${ }^{*}$ Francisco Javier Osorno-Covarrubias ${ }^{\text {b }}$ \\ ${ }^{a}$ Maestría en Geografía. Posgrado en Geografía de la Universidad Nacional Autónoma de México (UNAM). Circuito de Posgrados, SN, Edificio E, oficinas 103, \\ 104, 110, Ciudad Universitaria, Coyoacán, 04510, Ciudad de México, México. \\ ${ }^{b}$ Laboratorio de Análisis Geo-Espacial (LAGE), Instituto de Geografía, Universidad Nacional Autónoma de México (UNAM), Circuito Exterior, Ciudad \\ Universitaria, Coyoacán, Apdo Postal 20850, CP 04510, Ciudad de México, México.
}

\begin{abstract}
This paper presents an interactive geo-visualizer on the incidence of Covid-19 cases, as well as the associated mortality, in the US-Mexico cross-border strip. This tool allows to compare the evolution of the pandemic process in border municipalities and counties, using interactive graphs that show accumulated case and death curves. The map includes the information of confirmed cases of Covid-19 until August 31, 2020 in the 25 US counties and 38 Mexican municipalities adjacent to the border line, which extend from San Diego/Tijuana to Cameron/Matamoros. It also includes information on the number of border crossings per person from January to July 2020, the purpose of which is to compare the incidence of cases with the behavior of cross-border mobility.
\end{abstract}

Keywords: border; cross-border; Mexico; United States; covid-19; coronavirus; geovisualization

\section{Resumen}

Se presenta un visualizador interactivo de la incidencia de casos de COVID-19 y la mortalidad asociada, en el franja fronteriza México-Estados Unidos. Esta herramienta permite comparar la evolución del proceso pandémico en los municipios y condados fronterizos, a través de gráficas interactivas de las curvas de acumulación de casos confirmados y defunciones. El mapa incluye los indicadores referidos, con información recabada hasta el 31 de agosto de 2020, para los 25 condados y 38 municipios adyacentes a la franja fronteriza que se extiende de San Diego/Tijuana, hasta Cameron/Matamoros. También presenta información referente al cruce de personas, durante el periodo de enero a julio de 2020, con el objeto de explorar el efecto de la movilidad transfronteriza sobre la incidencia de casos.

Palabras clave: frontera; movilidad transfronteriza; México; Estados Unidos; covid-19; coronavirus; geovisualización

\section{Introduction}

The border between Mexico and the United States presents the highest number of crossings in the world, with an annual volume of 350 million documented crossings (Andreas, 2009). In term of trading Mexico is the third partner for the US whereas

(C) I. A. Martínez Zazueta, F. J. Osorno-Covarrubias This is an Open Access article distributed under the terms of the Creative Commons Attribution License (https://creativecommons.org/licenses/by-nc-sa/4.0/), which permits non-commencial sharing of the work and adaptions, provided the original work is properly cited and the new creations are licensed under identical terms.

*E-mail address: ivan.martinez.zta@gmail.com the US is the first for Mexico, with an exchange volume in the order of 671 billion a year (Office of the US trade representative, 2020). These flows have been disrupted by the COVID-19 pandemic with economic and social costs not yet quantified. From an epidemiological point of view, Mexico and the US shares a high incidence of COVID-19 cases. In terms of number of deaths, they occupy the fourth and first place respectively (CSSE at JHU, 2020).

Despite the restrictions on border crossing, imposed as of March when the epidemic began to take hold on both sides of the border, the data indicates that the flow of people continues at a level such that a close coupling in the dynamics of the pandemic on both sides of the border, is expected (Badr et al., 
2020).

The purpose of the geo-viewer is to provide a tool that allows one to explore the incidence of cases and deaths from COVID-19 on an interactive map of the Mexican municipalities and US counties adjacent to the border (See map), as well as a comparison of epidemic curves and variations in cross-border mobility during the health contingency.

\section{Methodology}

We seek to describe and characterize the epidemiological process in the border area and communicate the results through an interactive visualizer. We use as epidemiological indicators the incidence of confirmed cases and the death count, as well as the respective rates, only in the border area, with a cutoff of August 2020. For this we collect data from the CDC and the health ministry Mexico (CDC, 2020; Secretaria de Salud, 2020; CONACYT et al., 2020). The cartography and population data come from INEGI (2020) and the US Census Bureau (2010). Given the impact of mobility in a pandemic process and being a border area, we add monthly information on the cross-border flow of people from the US Department of Transportation (2020).

Our characterization of the phenomenon consists of three elements: statistical, spatial and temporal description of the indicators. For the first element, we use graphs, measurements of central tendency and dispersion, classification schemas, identification of extreme cases, among others. For the second, we use maps that highlight the spatial properties of the phenomenon, such as concentration-dispersion, adjacency and connectedness. For the third, we use graphs that show the dynamics of the indicators, presenting relevant data grouped by day, week, month and accumulated since the beginning of the pandemic.

Data preparation involved several steps of restructuring and aggregating the source data to obtain a common structure. For this we use Python scripts and SQL queries, in a PostgreSQL database adapted for handling geospatial data through the PostGIS extension. The subsequent analysis of the refined data follows three routes: 1) the description and exploration of the statistical properties through R-Studio 2) the exploration and presentation of the spatio-temporal properties through QGIS and R-studio and 3) the presentation of the results through interactive web charts and maps based on PHP, OpenLayers and D3.js.

In the next section we present results for the descriptors referred above, moving from the general to the particular. We first consider aspects related to the entire period in the two border strips and then we move on to examining regions and municipalities, with data disaggregated by month, week and day.

\section{Results}

\subsection{Confirmed cases}

Adding the cases from both sides, 221,413 have been tested positive for Covid-19. Of these, $80.7 \%(178,731)$ are registered in the United States and only $19.3 \%(42,682)$ in Mexico (figure 1a). Note that the population on both sides of the border is very similar: on the Mexican side there are $7.74 \mathrm{M}(49.6 \%)$ and on the US side there are $7.85 \mathrm{M}(50.4 \%)$. Hence, the incidence rate per 10K inhabitants on the United States side is 227.7 and on the Mexican side 55.1.

\subsection{Deaths}

Adding the cases on both sides of the border 10,654 deaths where registered. Of these, $54.6 \%(5,816)$ occurred in Mexico and $45.4 \%(4,838)$ occurred in the United States. This ratio is closer to the corresponding population proportions.

\subsection{Comparison of the number of tests per capita}

Figure 2a shows a scatter diagram of the number of tests with a positive result considering the population and country. Note that the dispersion around a central tendency for all the points of a country is much smaller than the dispersion of the points between both countries. This pattern confirms the information that can be obtained from documentary sources, which points to a more aggressive testing policy on the US side, in contrast to that of Mexican, aimed at confirming the diagnosis in patients who already have symptoms (Roser et al, 2020)1. Figure $2 \mathrm{~b}$ presents the geographic location and ranking of the 13 geographic units (county or municipality) with the highest number of confirmed cases. Note that the first eight places correspond to counties and the next 5 to municipalities.

This disparity in the test application rate limits the usefulness of the indicator "positive results" to comparisons within the same country.

\subsection{Accumulated number of deaths and death rate by $G U$ :}

Figure 3a shows a scatter diagram of the accumulated number of deaths vs the population by municipality and country. Unlike graph 2a, this does not show trends separated by country. The cases of Mexicali BC, Tijuana BC and Hidalgo TX stand out well above the general trend. At the extreme right of the graph, San Diego County stands out with a relatively low cumulative number of deaths for its population size. Figure 3b) show this trend more clearly. Note in the upper right corner, a cluster of counties with very high mortality rates and relatively small populations. In figure $3 \mathrm{c}$ we present a map of the $13 \mathrm{GU}$ with the highest accumulated number of deaths (blue rank) and highest death rate (red numbers). These 13 units concentrate the $80 \%$ of deaths.

\subsection{Pairs county-municipio that share a common border}

A common working hypothesis in geography is to assume that nearby or contiguous geographic entities tend to resemble each other more than distant entities (Tobbler's law). Does this conjecture hold for the mortality rate of municipality-county pairs that share a common border? Almost all counties are 

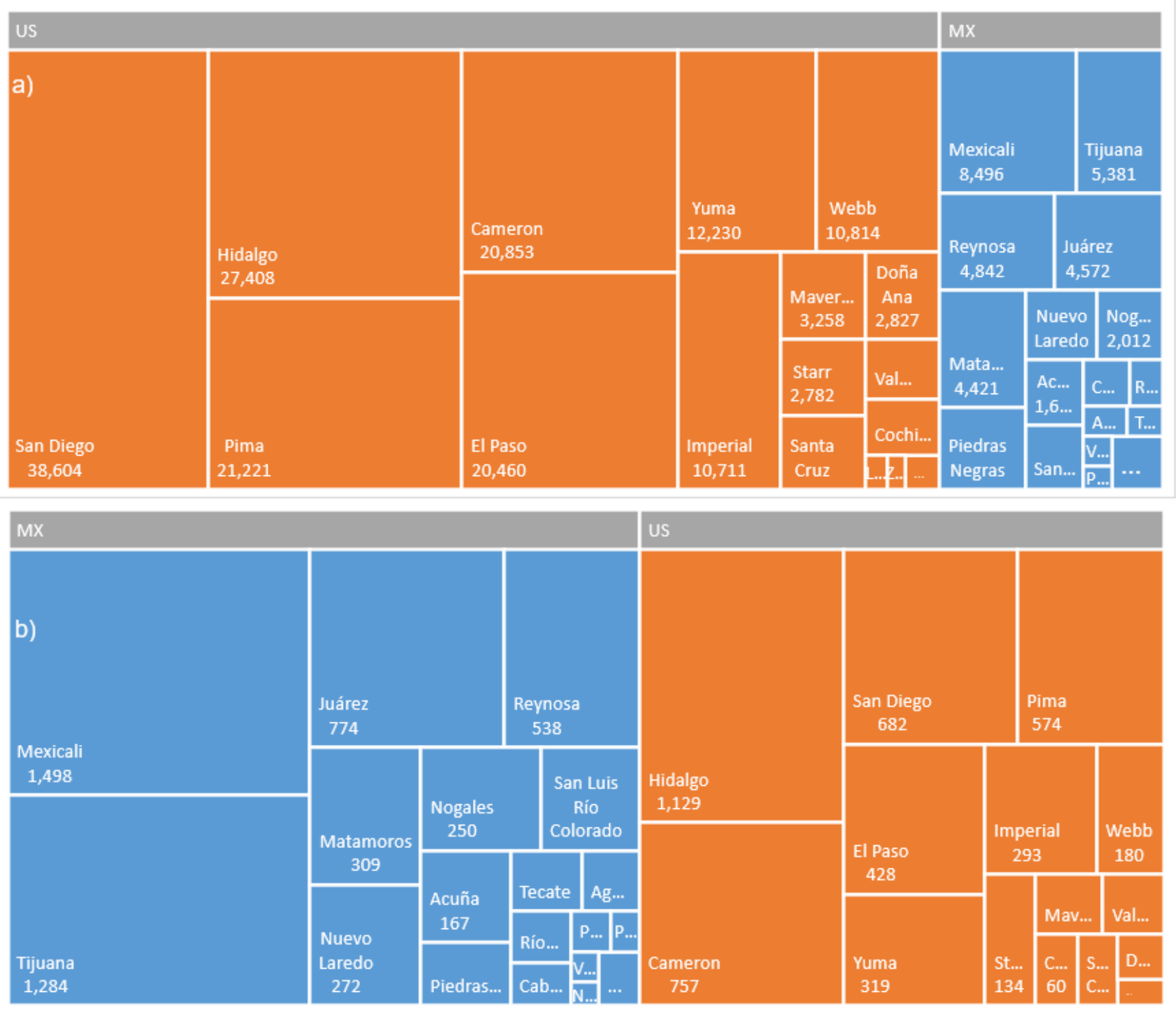

Figure 1: Total confirmed cases and deaths on both sides of the border as of August 31, 2020. The proportion (size of the table) and cumulative number cases in each county or municipality are shown. a) Confirmed cases b) Deaths. / Figura 1. Total de casos confirmados y defunciones en ambos lados de la franja fronteriza, al 31 de agosto de 2020. Se muestra la proporción (tamaño del recuadro) y número acumulado de casos en cada condado y municipio. a) Casos confirmados b) Defunciones.

larger than contiguous municipalities, so there are 39 municipalities and 24 counties. To prove the aforementioned conjecture, we group in pairs all the municipalities that share a border with a county or, in the few cases where this occurs, all the counties that cover the border of a municipality. We add the deaths and populations and calculate the mortality rate for the municipalit(y/ies)-count(y/ies) "pairs" and apply a Spearman correlation test on the mortality rate (figure 4).

\subsection{Mobility through border checkpoints}

Given the relevance of mobility as a factor that catalyzes the spread of the pandemic, many countries have imposed re- ductions or temporary closures of border posts. How much was mobility reduced between both countries? When? Is there any degree of association between the number of crosses and the accumulated number of deaths in the geostatistical units connected? Figure 5 a) shows the monthly evolution of the number of crossings of people per month for eight of the 24 border checkpoints. These concentrate $82 \%$ of the flow between the two countries. Note the gradual reduction from February 2020 to reach a minimum in March, when the flow is reduced to 30\% compared to the same month the previous year. Subsequently, the number of crosses recovered slightly, stabilizing for several months at $40-45 \%$ normal flow. b) The geographical location 
40000 -

a)

$30000-$

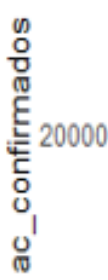

10000 -
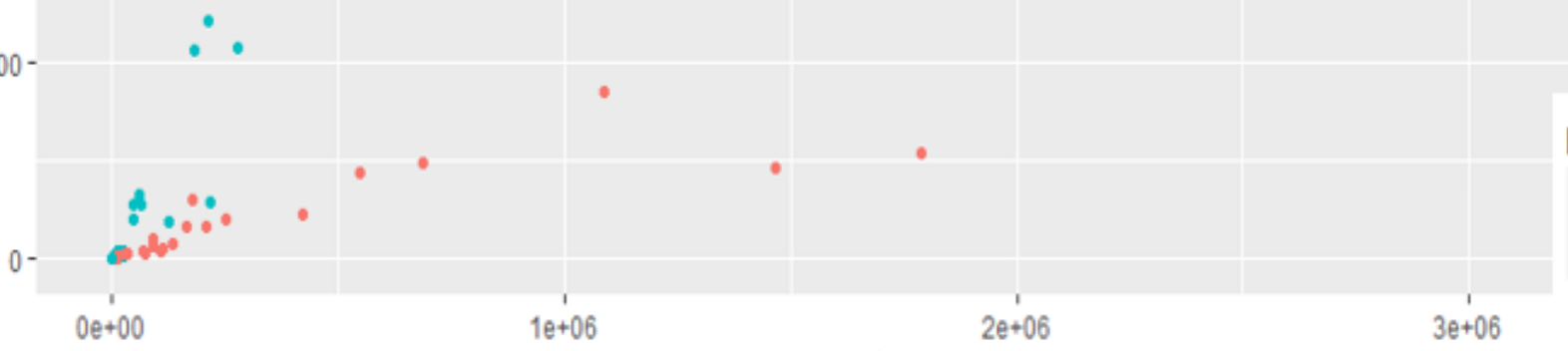

b)

\begin{tabular}{|l|c|}
\hline D) \\
\hline
\end{tabular}

pob

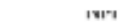

Figure 2: Confirmed cases by Geostatistical Unit (GU). a) Scatter diagram of the number of confirmed cases according to population and country. The $\mathrm{x}$ axis is the population in millions, the y-axis shows the cumulative number of confirmed cases. b) Location and ranking of the GUs (counties or municipalities) according to the number of confirmed cases. We applied a Pareto cutoff criterion. These GUs ( $20 \%$ of the 65 GUs), account for $86 \%$ of confirmed cases. / Figura 2. Casos confirmados por Unidad Geoestadística (UG: condado o municipio). a) diagrama de dispersión del número de casos confirmados de acuerdo con la población y país. El eje x muestra la población en millones. El eje y muestra el número acumulado de casos. b) Ubicación geográfica y rango de las UGs según el número de casos confirmados. Aplicamos corte de Pareto de manera que se muestran solo el 20\% de las GUs que acumulan el $86 \%$ de los casos confirmados. 


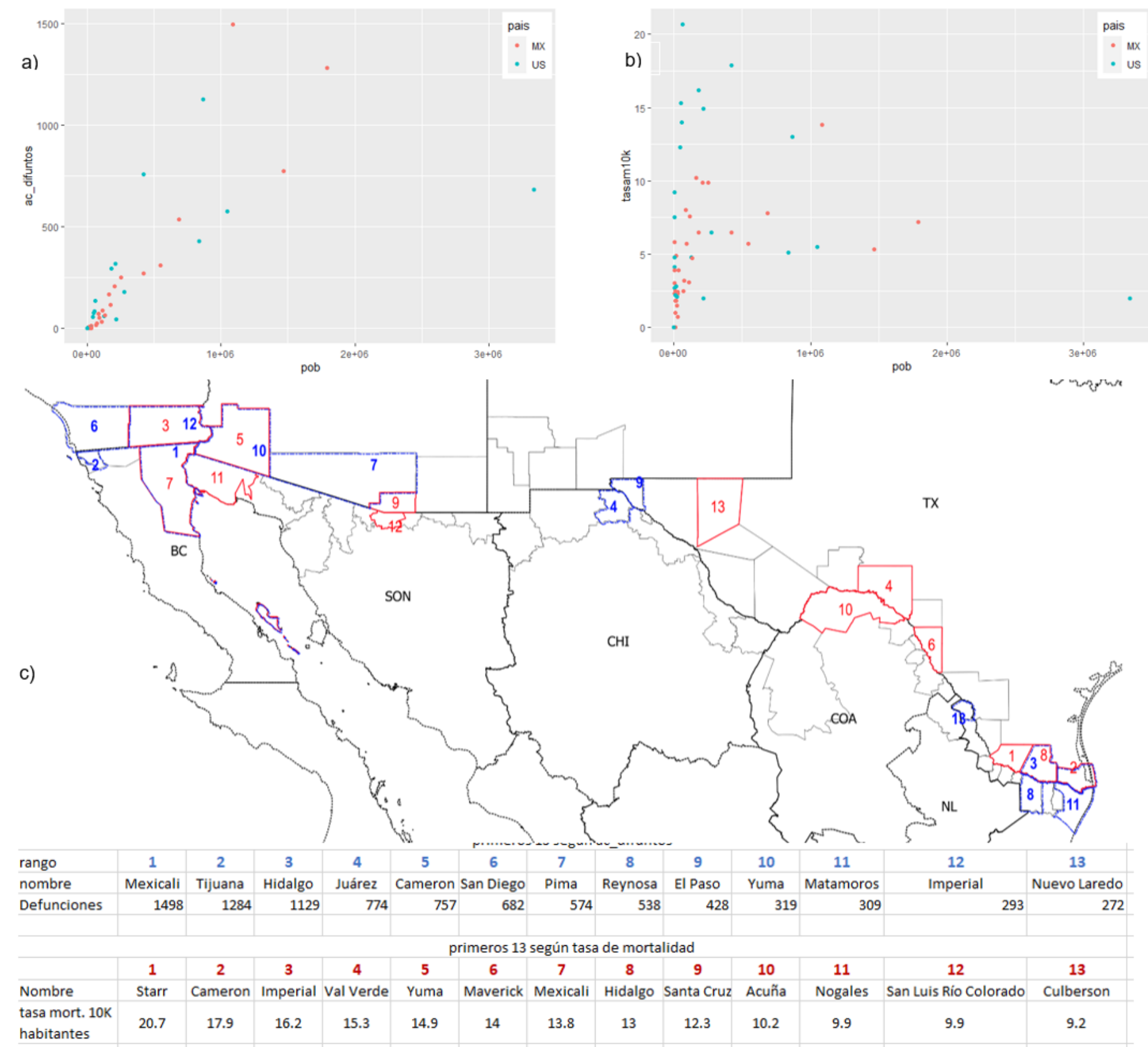

Figure 3: a) Scatter plot of the accumulated number of deaths by GU according to its population. b) Scatter plot of the date rate by GU, according to its population. c) Geographic distribution of the municipalities with highest number of deaths (blue) and mortality rate (red). / Figura 3. a) Diagrama de dispersión del número acumulado de defunciones por UG, según su población. b) Diagrama de dispersión de la tasa defunciones en la UG según su población c) Distribución geográfica de las UG con más alto número de defunciones (azul) y tasa de mortalidad (rojo). 

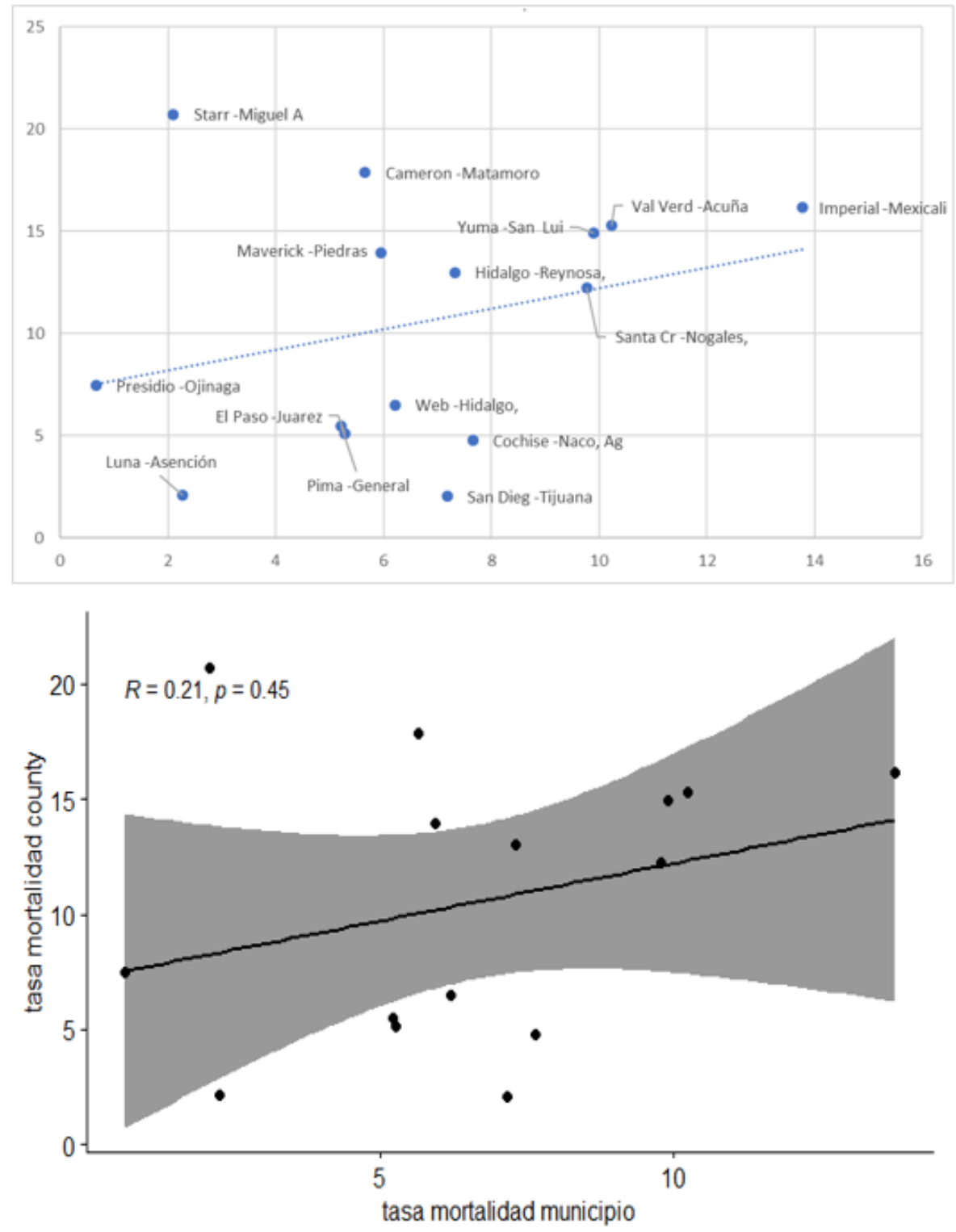

Figure 4: Mortality rate vs: county-municipality tuples. a) In each tuple [municipality, county] there can be from 1 to $\mathrm{n}$ municipalities and 1 to $\mathrm{m}$ counties. b) Sperman correlation / Figura 4. Tasa de mortalidad vs: tuplas condado-municipio. a) cada tupla [municipio(s), condado(s)] esta integrada por el par que agrupa los 1 a n municipios y 1 a m condados que tiene frontera común. b) correlación de Spearman correspondiente. 

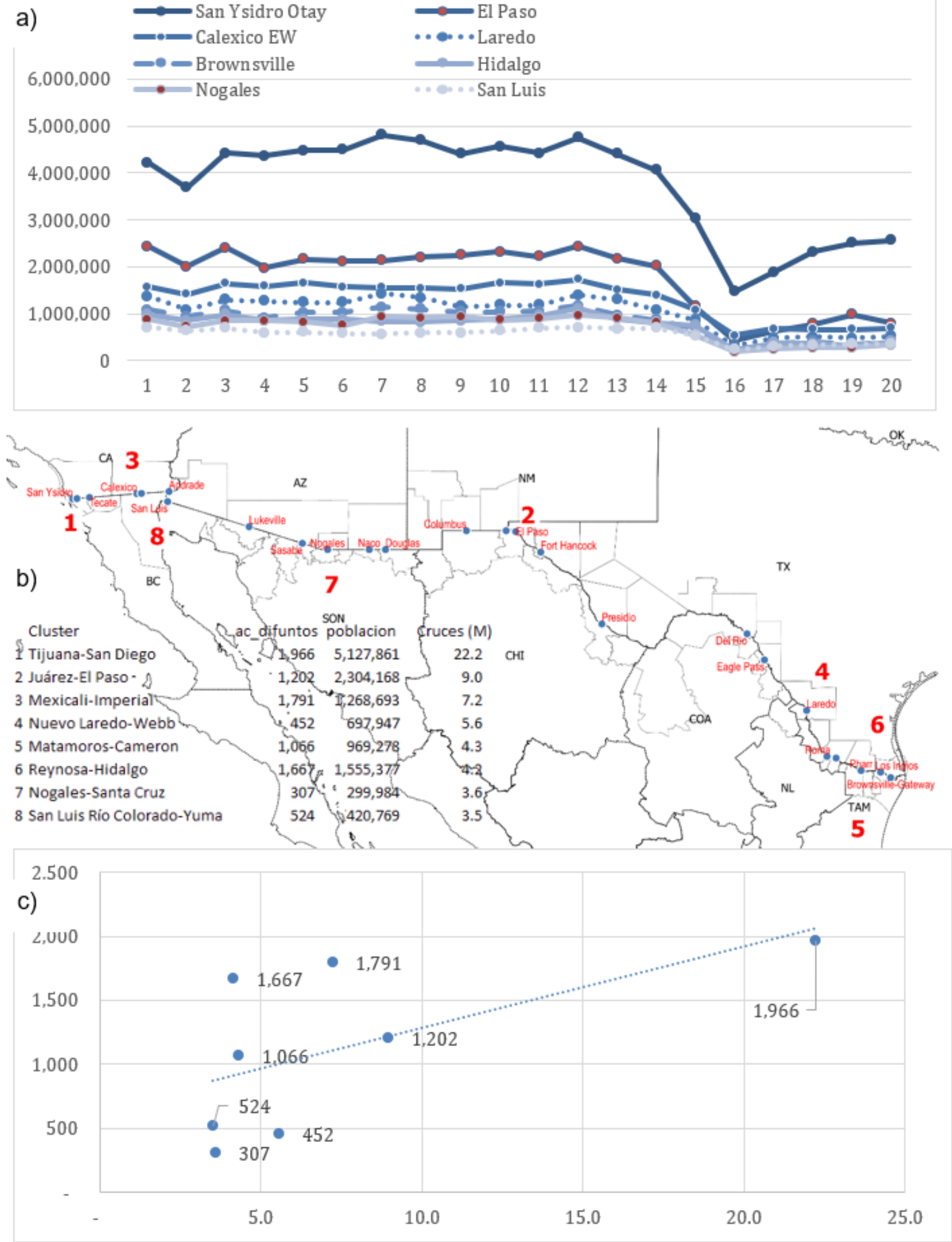

Figure 5: a) Monthly evolution of the number of crossings per month. b) Geographical location of the main border gates is shown c) scatter plot of accumulated deaths vs: accumulated number of persons entering United States (M) during the period from March to August / Figura 5. a) evolución mensual del cruce de personas por mes. b) Se muestra la ubicación geográfica de las principales garitas fronterizas c) diagrama de dispersión del número acumulado de defunciones vs: ingreso de personas a Estados Unidos (Millones) durante el periodo de marzo a agosto de 2020 
of the main border posts is shown. To explore the possible association between the number of crosses and the accumulated number of deaths, we added the death records and plotted them against the number of admissions from March to August.

Figure 6 shows a positive correlation of 0.77 with a high level of certainty: $p=0.0013$

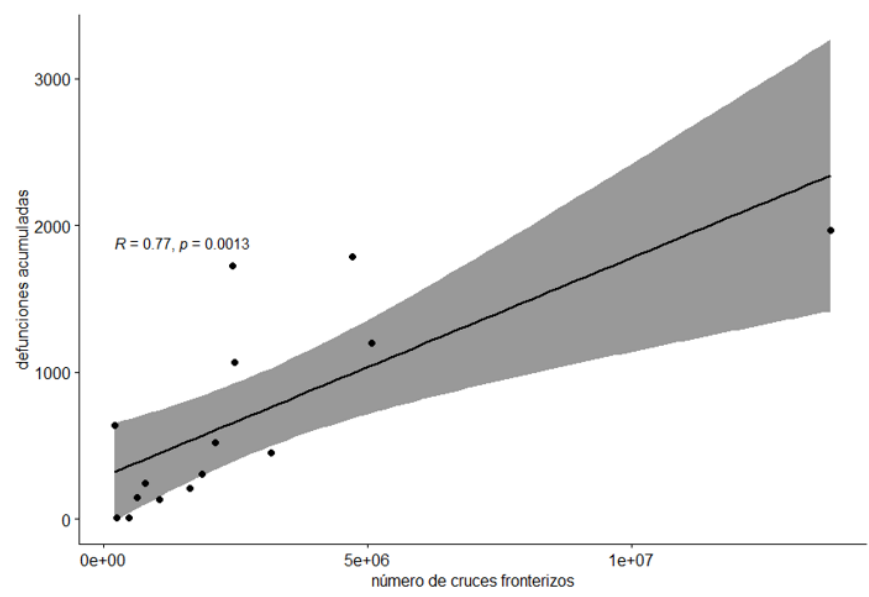

Figure 6: Spearman correlation between the number of border crossings and cumulative number of deaths. / Figura 6. Correlación de Spearman del número del número acumulado de muertes vs: número de cruces fronterizos

\subsection{Evolution of the number of deaths}

Some relevant attributes for the description of the pandemic process are the moment in which the local spread of infections or deaths begins, the speed with which they increase or decrease, when the maximums occur, if there are rebounds and if there is synchrony between neighboring GU. In figure 7a) we group the deaths by week as of August 31, for the $13 \mathrm{GU}$. Of note is the high number of deaths in San Diego County, which remained comparatively high throughout the period. The contiguous municipalities Tijuana and Mexicali start from a similar level. The number of deaths accelerates rapidly in Tijuana, reaching a peak of 144 deaths in the sixth week. On the east side of the border, in Hidalgo and Cameron counties, the onset of deaths occurs until week 11. From there it accelerates until reaching a peak of 264 during week 19 . This peak almost doubles the previous maximum registered in Tijuana. Figure $7 \mathrm{~b}$ presents the cumulative number of deaths broken down by day. The fastest growing curves is that of Hidalgo TX. Its curve reaches the end of the period without flattening. That of Cameron TX presents a maximum slope similar to those of Tijuana and Mexicali, although it begins to accelerate from week 12.

\section{Interactive map design and implementation}

The interactive map was designed based on the following considerations:
1) Four views were defined for the layer of municipalities and counties: a) Death rate per 10,000 inhabitants; b) Cumulative number of deaths; c) Rate of positive cases per 10,000 inhabitants, and d) Cumulative number of positive cases. Another layer of information available on the map is that of border crossings, associated with points that represent migratory checkpoints. Its size varies depending on the number of monthly crosses, from January to August 2020.

2) Different color gradients for each country are used to represent the rate and accumulated number of confirmed cases in order to reflect the fact that this indicator depends strongly on the number of tests per capita (see figure 2a).

3) On the other hand, given that the death registry is comparable in both countries, a single color gradient was used to represent the rate and accumulated number of deaths;

4) The cut-off points in the cartographic styles were classified with the method of Natural Breaks (Jenks) which defines intervals in such a way that the variance within each group is minimized while the variance between groups is maximized. We selected five groups to which we assign the legend "Very low", "Low", "Medium", "High" and "Very high", respectively.

5) User controls were added that allow to switch between indicators (Deaths and confirmed cases) and view mode (rate or accumulated number). When selecting a municipality or a county, the cumulative curve of the active indicator is displayed in a plot. A control is included to examine the monthly variations in the number of border crossings, before and during the pandemic. Also, when the user hovers the mouse cursor on a municipality/county or a border crossing point, a window is displayed with a summary of cases and rates and with the number of crossings, respectively.

\section{Discussion}

In this section we present the spatial distribution of the indicators proposed in this work, grouped by the natural breaks method.

\subsection{Rate of confirmed cases}

On the Mexican side, the municipality of Caborca stands out, as the only one with a confirmed rate of Very High (VH) indicating a very high number of infections in relation to the population. In the High $(\mathrm{H})$ group there are 9 municipalities, 7 of which are adjacent to counties in the VH group. On the US side we find 6 counties in the VH group. Note that the $\mathrm{VH}$ group on the Mexican side roughly corresponds to the Low (L) group on the US side (figure 8).

In general, a positive correlation is observed between adjacent groups on both sides of the border.

\subsection{Mortality Rate}

As we noted earlier for the death rate indicator, we use the same cut-off points for counties and municipalities (figure 9). There are 2 GUs in the VH group: Star (20.7) and Cameron 


\section{difuntos por municipio-semana}

\begin{tabular}{|c|c|c|c|c|c|c|c|c|c|c|c|c|c|c|c|c|c|c|c|c|c|c|}
\hline Mexicali, BC & 8 & 19 & 24 & 28 & 44 & 58 & 102 & 140 & 130 & 132 & 141 & 108 & 114 & 117 & 113 & 75 & 77 & 64 & 56 & 36 & 43 & 34 \\
\hline Tipuana, BC & 10 & 27 & 76 & 104 & 123 & 144 & 131 & 107 & 86 & 87 & 59 & 49 & 34 & 58 & 76 & 47 & 38 & 50 & 48 & 45 & 46 & 31 \\
\hline Juárez, Chilh & 3 & 19 & 26 & 49 & 49 & 64 & 69 & 62 & 64 & 63 & 71 & 55 & 37 & 31 & 37 & 26 & 30 & 34 & 33 & 29 & 15 & 23 \\
\hline Matamoros, Jam & 0 & 0 & 1 & 6 & 5 & 7 & 12 & 9 & 8 & 10 & 9 & 11 & 19 & 27 & 35 & 28 & 37 & 37 & 17 & 23 & 21 & 19 \\
\hline Nuevo Laredo, Son & 1 & 2 & 1 & 0 & 0 & 5 & 5 & 5 & 5 & 7 & 4 & 5 & 12 & 26 & 31 & 38 & 34 & 37 & 29 & 20 & 22 & 19 \\
\hline Reynosa, Tam & 1 & 0 & 0 & 0 & 4 & 3 & 2 & 3 & 7 & 11 & 22 & 72 & 90 & 103 & 98 & 63 & 44 & 34 & 24 & 18 & 16 & 8 \\
\hline Pima, Al & 12 & 18 & 30 & 25 & 15 & 52 & 26 & 18 & 12 & 20 & 21 & 20 & 28 & 16 & 44 & 69 & 50 & 45 & 30 & 48 & 27 & 42 \\
\hline Yuma, Al & 0 & 0 & 0 & 1 & 0 & 2 & 3 & 4 & 7 & 11 & 19 & 22 & 28 & 22 & 39 & 52 & 55 & 34 & 31 & 12 & 12 & 20 \\
\hline Imperial, $C A$ & 1 & 2 & 0 & 5 & 1 & 3 & 3 & 8 & 4 & 7 & 10 & 21 & 17 & 41 & 30 & 29 & 25 & 47 & 34 & 15 & 15 & 24 \\
\hline San Diego, CA & 18 & 28 & 27 & 48 & 36 & 41 & 40 & 41 & 27 & 36 & 25 & 25 & 28 & 29 & 35 & 58 & 61 & 41 & 32 & 40 & 38 & 27 \\
\hline Cameron, $\mathrm{XX}$ & 0 & 3 & 2 & 10 & 6 & 4 & 6 & 6 & 4 & 4 & 5 & 4 & 6 & 11 & 17 & 20 & 80 & 193 & 100 & 132 & 120 & 117 \\
\hline El Paso TX & 0 & 2 & 6 & 3 & 12 & 11 & 15 & 15 & 20 & 13 & 10 & 22 & 8 & 9 & 15 & 29 & 39 & 32 & 40 & 61 & 64 & 41 \\
\hline Hidalno, TX & 0 & 1 & 2 & 1 & 2 & 1 & 3 & 0 & 0 & 1 & 1 & 9 & 11 & 29 & 66 & 137 & 26 & 168 & 264 & 177 & 228 & 179 \\
\hline
\end{tabular}

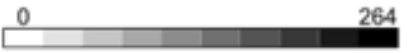

\section{Número acumulado de muertes por Covid-19}

1600

1400

1200

1000

800

600

400

200

0

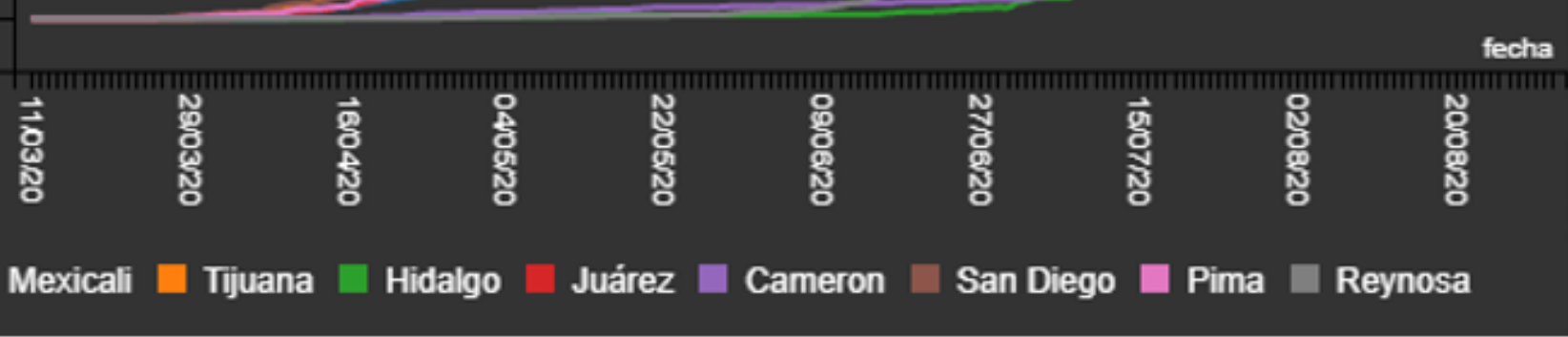

Figure 7: Dynamics of deaths by municipality from March 11 to August a) Deaths per week by municipality: b) death accumulation curve. / Figura 7. Dinámica de la acumulación de defunciones por UG entre marzo y agosto a) Defunciones por semana b) curva de acumulación de defunciones.

(17.9). In group $\mathrm{H}$ there are 7 , only one from the Mexican side: Mexicali (13.8). This is consistent with the low correlation found in figure 4. Almost half of the GUs (30 out of 65) are grouped in group VL group with mortality rates below 3.2 per 10,000 .

\subsection{Relation between mortality rate and border crossing}

Given the correlation found between accumulated deaths and the number of border crossings (figure 7), is there a relationship between the mortality rate and the number of crossings per port of entry? 
Note that almost all the mayor border posts connect countymunicipality pairs, with mortality rates in the VL or L group (figure 10a). The low significance of the correlation $(\mathrm{p}=0.49)$ can be attributed to several factors 1$)$ to the fact that the re-

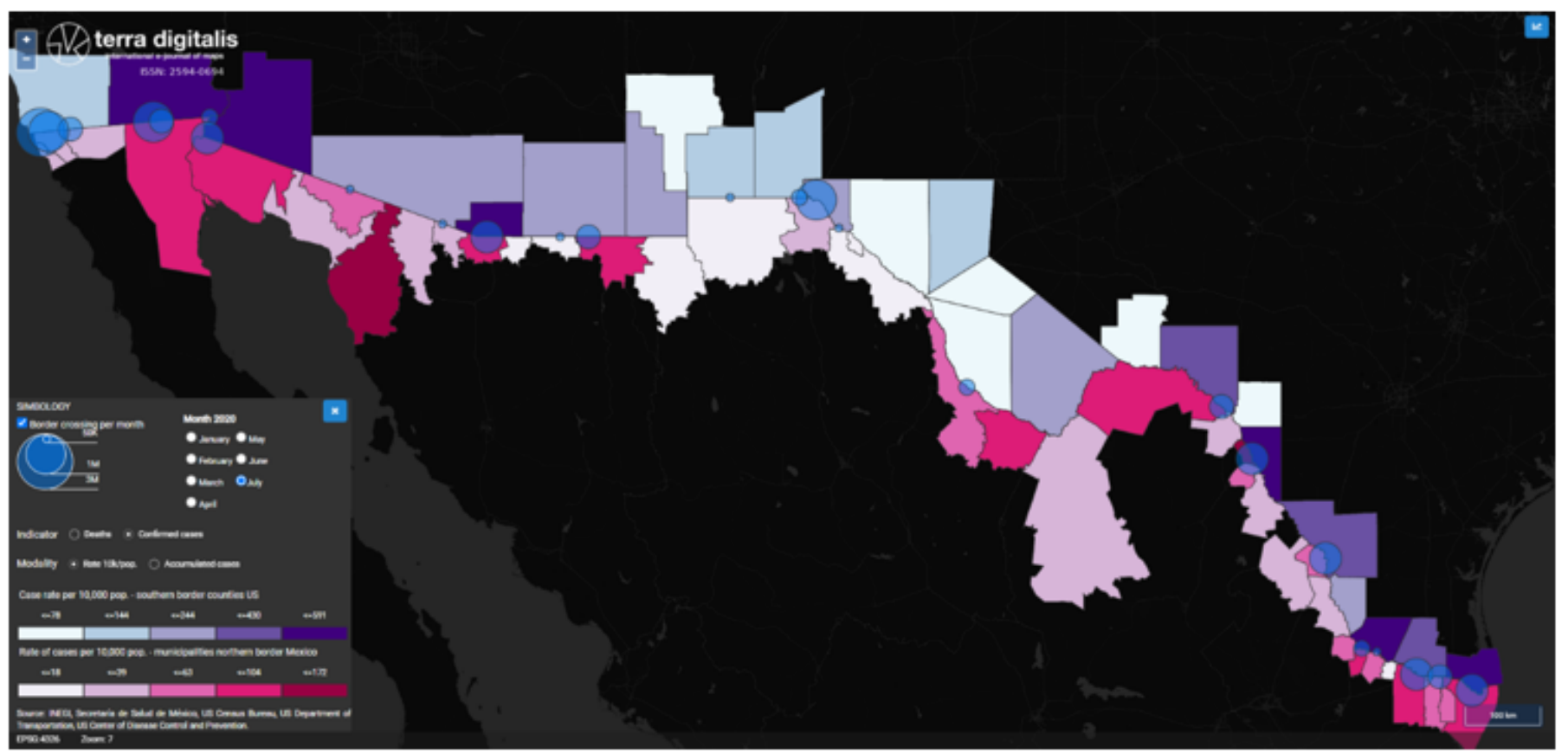

Figure 8: Confirmed cases rate per 10,000 population in the border counties and municipalities, by August 31, 2020. Own elaboration based on data from the Secretaría de Salud (2020); Centers for Disease Control and Prevention (2020). / Figura 8. Tasa de casos confirmados de covid-19 por 10K habitantes en condados y municipios fronterizos, hasta agosto de 2020. Elaboración propia a partir de datos de la Secretaría de Salud, 2020 y el Center for Disease Control and Prevention, 2020

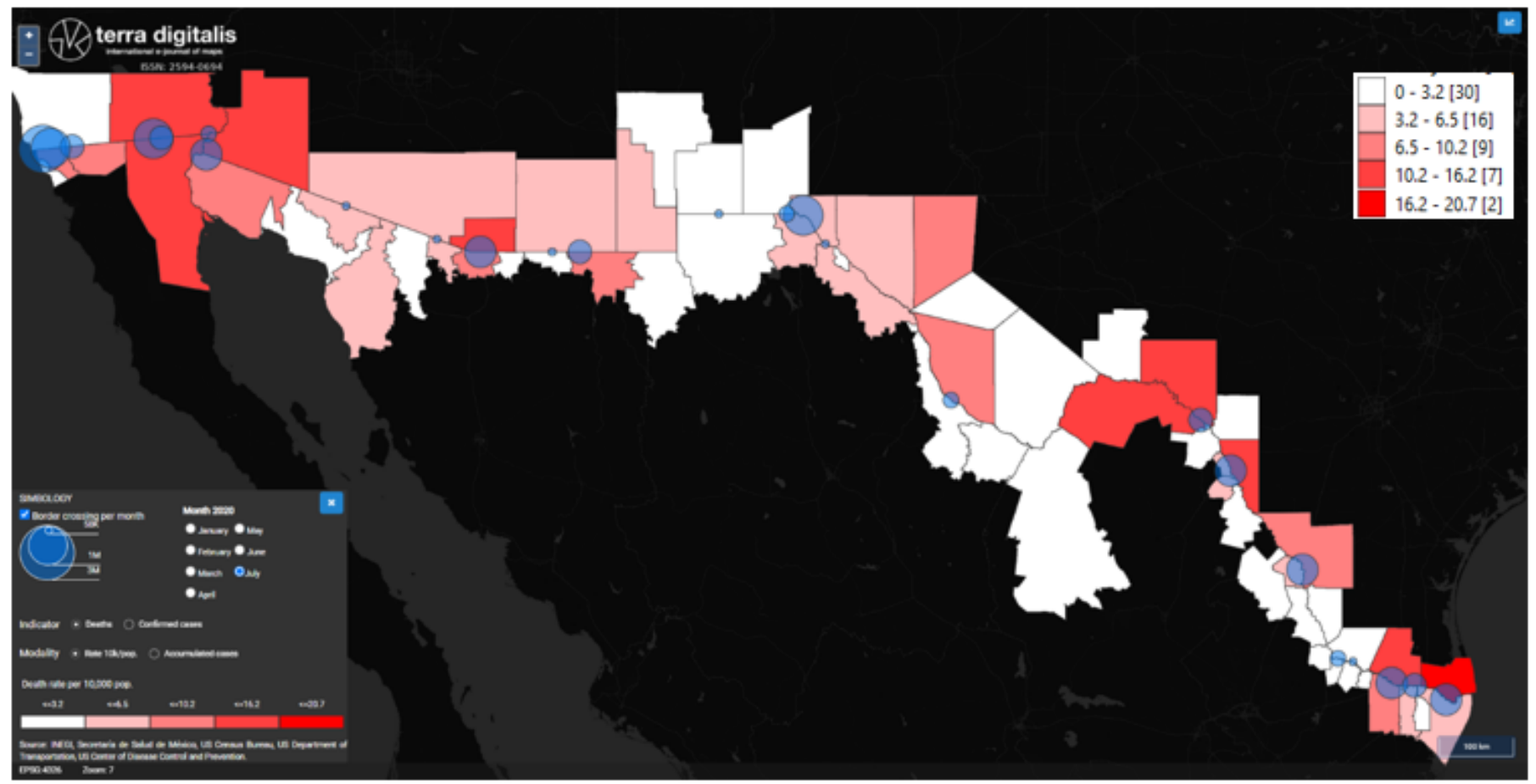

Figure 9: Death caused by Covid-19 rate per 10,000 population, by August 31, 2020. Own elaboration based on data from the Secretaría de Salud (2020); Centers for Disease Control and Prevention (2020). / Figura 9. Tasa de defunciones por covid-19 por 10K habitantes. Elaboración propia a partir de datos de la Secretaría de Salud, 2020 y el Center for Disease Control and Prevention, 2020 

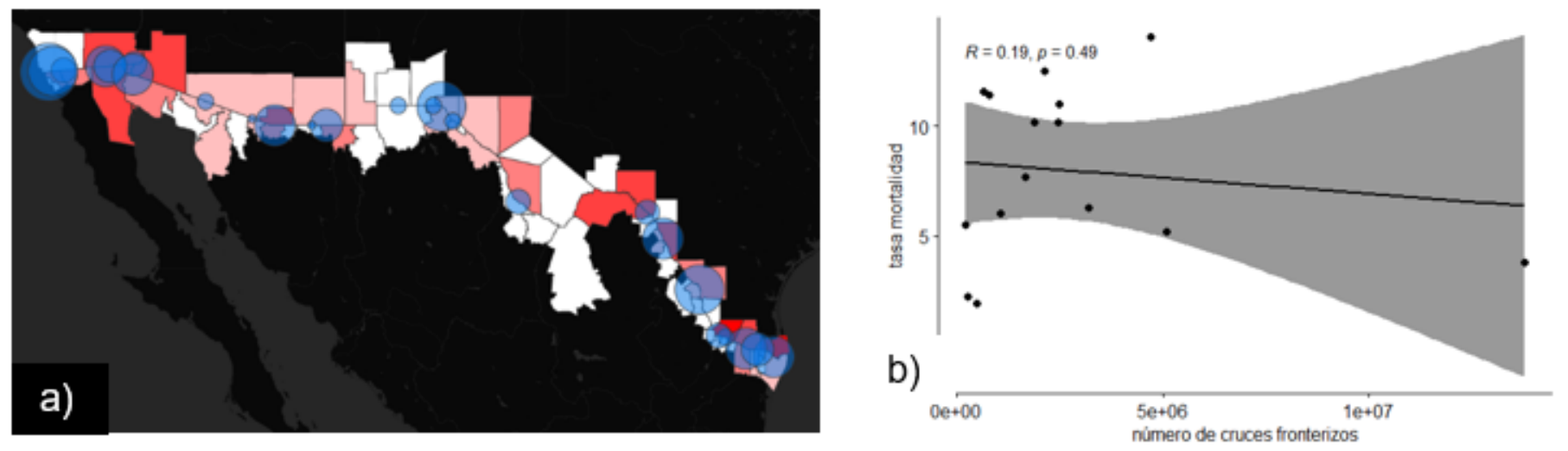

Figure 10: Relationship between the number of crossings per border post and the mortality rate in the connected GU. a) Mortality rate and border crossings in February 2020 b) Spearman correlation. / Figura 10. Relación entre el número de cruces de personas por garita fronteriza y la tasa de mortalidad en los UG conectadas. a) Tasa de mortalidad y cruces fronterizos en agosto. b) correlación de Spearman.

duction in the number of crosses would have to be much more drastic to have an appreciable effect. 2) the spatial and temporal granularity of the data, is too rough to discern the relationship between mobility and incidence. Being a descriptive study focused on narrow factors, it presents limitations.

Although the United States government determined the suspension of a large number of economic activities, those considered essential remained inn operation, some of which employ Mexican migrant labor. An essential sector that has remained in operation during the pandemic is that of agro-industrial production, in which California has a great importance, since it concentrates between a third and a half of the day laborer employed in the United States. A significant part of this labor sector is made up of migrant, immigrant and Mexican workers, who represent 19\% of the total (Santos and Sánchez, 2020). Many of these workers are transmigrants (commuters), that is, they have temporary permits (H-2A visas or green cards), reside in Mexico and cross the border on a daily or weekly basis. In this sense, the case of the agricultural valleys of Imperial and Coachella stands out, as their workforce includes a significant percentage of workers who reside in Mexicali (Fimbres and Ortega, 2001).

The case of the Export Maquiladora Industry stands out, in which Baja California is the state with the largest number of establishments (INEGI, 2020), many of which were reopened after a brief period of suspension with the argument of guaranteeing the operation of the called "supply chains", which had an impact on the increase in infections in the local labor sector (Sandoval, 2020).

\section{Conclusions}

This is just one reading of many, which shows the need to address the fight against the pandemic on the northern Mexican border and the southern US border from a cross-border approach. Likewise, the maps highlight the importance of cartography and geography in confronting the spread of the virus, but at the same time, they show some limitations of traditional cartography, since the pandemic is a dynamic phenomenon that changes every day. In this sense a constant update of maps is needed. Geo-visualization tools and interactive data dashboards are essential to face a phenomenon as complex and changing as the current pandemic.

\section{Funding}

The authors received no financial support for the research, authorship, and/or publication of this article.

\section{References}

Andreas, P., 2009. Border games: Policing the US-Mexico divide. Cornell University Press.

Badr, H. S., Du, H., Marshall, M., Dong, E., Squire, M. M., Gardner, L. M., 2020. Association between mobility patterns and COVID-19 transmission in the USA: a mathematical modelling study. The Lancet Infectious Diseases 20 (11), 1247-1254, https://doi.org/10.1016/S1473-3099(20)30553-3.

Center for Systems Science and Engineering (CSSE) at Johns Hopkins University (JHU), 2020. COVID-19 Dashboard. [Online]. https://arcg.is/0fHmTX (Accessed 15 August, 2020).

CONACYT, CentroGeo, GeoInt, DataLab, 2020. Covid-19 Tablero México. [Online]. https://coronavirus.gob.mx/datos/ (Accessed August 20, 2020).

Fimbres Durazo, N., Ortega Villa, G., 2001. Inmigración y movilidad laboral de trabajadores mexicanos residentes legales en una ciudad fronteriza de Estados Unidos: Caléxico, California. Estudios fronterizos 2 (3), 9-40, https://doi.org/10.21670/ref.2001.03.a01.

INEGI, 2010. Censo de Población y Vivienda 2010. [Online]. www.inegi.org.mx/programas/ccpv/2010/ (Accessed August 10, 2020).

INEGI, 2020. Programa de la industria manufacturera, maquiladora y de servicios de exportación (IMMEX) - 2007 en adelante. [Online]. https://www.inegi.org.mx/programas/immex/default.html (Accessed August 23, 2020).

Office of the United States Trade Representative, 2020. U.S.-Mexico Trade Facts. [Online]. https://tinyurl.com/y2agyqop (Accessed 15 August, 2020).

Roser, M., Ritchie, H., Ortiz-Ospina, E., Hasell, J., 2020. Coronavirus Pandemic (COVID-19). Our World in Data. [Online]. https://ourworldindata.org/coronavirus (Accessed August 20, 2020).

Sandoval, F., 2020. En Baja California, 14\% de los casos positivos por COVID-19 son empleados y obreros de empresas activas. 
Animal Político, https://www.animalpolitico.com/2020/05/pacientes-covidbaja-california-empleados-obreros-empresas-activas/ (Accessed August 22, 2020).

Santos-Gómez, H., Sánchez-Gómez, M. J., 2020. El jornalero incómodo: trabajador esencial [pero] indocumentado. La Jornada del Campo, https://www.jornada.com.mx/2020/05/16/delcampo/articulos/jornaleroincomodo.html (Accessed August 22, 2020).

Secretaría de Salud, 2020. Sistema de Vigilancia Epidemiológica de Enfermedades Respiratoria Viral, Portal de Datos Abiertos del Gobierno Federal. [Data set]. https://datos.gob.mx/busca/dataset/informacion-referente-acasos-covid-19-en-mexico (Accessed August 22, 2020).

United States Census Bureau, 2010. 2010 Census Data. [Data set]. https://www.census.gov/ (Accessed August 20, 2020).
United States Center of Disease Control and Prevention (CDC), 2020. Coronavirus (COVID-19). [Data set]. https://cdc.gov/coronavirus/2019ncov/cases-updates/index.html. (Accessed August 20, 2020).

United States Department of Transportation - Bureau of Transportation Statistics, 2020. Border Crossing/Entry Data, 2020. [Data set]. https://www.bts.gov/content/border-crossingentry-data. (Accessed August $20,2020)$

This article accompanies the following material:

HTML:

https://doi.org/10.22201/igg.25940694e.2020.2.80

Dashboard: https://doi.org/10.22201/igg.25940694e.2020.2.80.169 